\title{
Physiological responses of Lupinus luteus to different copper concentrations
}

\author{
M.P. MOURATO ${ }^{1}$, L.L. MARTINS ${ }^{1}$ and M.P. CAMPOS-ANDRADA ${ }^{2}$ \\ Departamento de Química Agricola e Ambiental, Instituto Superior de Agronomia, \\ Tapada da Ajuda 1349-017 Lisboa, Portugal \\ Departamento de Recursos Genéticos e Melhoramento, Estação Agronómica Nacional, \\ Quinta do Marquês 2784-505 Oeiras, Portugal²
}

\begin{abstract}
Yellow lupin (Lupinus luteus L.) plants were grown in hydroponic solution for $15 \mathrm{~d}$ under different copper concentrations $(0.1,0.5,1.0,10,25$ and $50 \mu \mathrm{M})$. With increasing $\mathrm{Cu}$ concentration total biomass was not affected, leaf area slightly decreased, while chlorophyll content decreased considerably. $\mathrm{Cu}$ content increased significantly both in roots and in leaves, but the contents of other ions were only slightly affected at the highest $\mathrm{Cu}$ concentration (Mn content decreased both in roots and in leaves, $\mathrm{P}$ content decreased only in leaves and $\mathrm{Zn}$ content increased in roots). Superoxide dismutase (SOD) activity increased up to day 7 after copper application. Peroxidase (GPOD) and polyphenol oxidase (PPO) activities also increased, while catalase (CAT) activity remained constant.
\end{abstract}

Additional key words: yellow lupin, oxidative stress, heavy metal toxicity.

\section{Introduction}

Copper is a plant micronutrient that is an essential component of several enzymes and coenzymes involved in metabolic pathways of plants. However, at high concentrations $\mathrm{Cu}$ can become phytotoxic affecting plant development due to direct or indirect interference with numerous physiological processes (Maksymiec 1997, Vangronsveld and Clijsters 1994). Described symptoms of copper phytotoxicity include stunted growth, leaf chlorosis (Baron et al. 1995, Fernandes and Henriques 1991), changes in mineral content and several enzyme activities (Brun et al. 2003, Maksymiec 1997, Mazhoudi et al. 1997, Mocquot et al. 1996). According to Clijsters et al. (1999) some of these changes may be observed before visible symptoms become evident.

One of the main effects of copper is the induction of oxidative stress, leading to the production of reactive oxygen species (ROS) that can cause the activation of different antioxidative pathways (Clijsters et al. 1999, Cuypers et al. 1999, Mazhoudi et al. 1997, Van Assche and Clijsters 1990). Enzymes can be activated which are implicated in the removal of superoxide (e.g. superoxide dismutase) and of $\mathrm{H}_{2} \mathrm{O}_{2}$ (like catalase and peroxidase) and those involved in the ascorbate-glutathione pathway (Gupta et al. 1999, Cuypers et al. 2000).

As yellow lupin seeds are used in animal feed, the possibility of plant uptake and accumulation of heavy metals in seed can be dangerous for both animal and human nutrition. However, to date, no studies of this subject have been carried out with this lupin species and copper toxicity. Brennan and Mann (2005) have shown that yellow lupins can accumulate more cadmium than other lupin species.

In order to improve our knowledge regarding the tolerance of yellow lupin plants to excess copper we studied the effect of this metal on fresh and dry matter, leaf area, chlorophyll content, contents of calcium, sodium, magnesium, potassium, phosphorus, copper, zinc, iron and manganese, and activities of guaiacol peroxidase (GPOD), catalase (CAT), superoxide dismutase (SOD) and polyphenol oxidase (PPO).

Received 10 May 2007, accepted 17 November 2007.

Abbreviations: CAT - catalase; d.m. - dry mass; f.m. - fresh mass; GPOD - guaiacol peroxidase; PPO - polyphenol oxidase; SOD - superoxide dismutase.

Acknowledgements: This work was partially funded by FCT project POCTI/AGG/44895/2002. The authors acknowledge the technical assistance of Ana Cristina Silva in some of the experimental determinations and of Dr. Giles Atkinson in reviewing the manuscript.

* Corresponding author; fax: (+35) 1 213653180, e-mail: mmourato@isa.utl.pt 


\section{Materials and methods}

Plants and copper treatments: Yellow lupin (Lupinus luteus L. cv. Cardiga) seeds were germinated in moist filter paper soaked with deionised water at a temperature above $20{ }^{\circ} \mathrm{C}$ for $7 \mathrm{~d}$. After germination, the seedlings were planted on perforated polystyrene plates, floating on an aerated Hoagland nutrient solution, which was renewed every week. The plants were grown for 6 weeks on hydroponic culture in a growth chamber at temperature of $18-24{ }^{\circ} \mathrm{C}$, relative humidity of $65 \%$, and 14-h photoperiod with irradiance of $250 \mu \mathrm{mol} \mathrm{m} \mathrm{m}^{-2} \mathrm{~s}^{-1}$. After that, plants were treated with nutrient solutions containing different copper concentrations: $0.1 \mu \mathrm{M}$ (control), 0.5, 1.0, 10, 25 and $50 \mu \mathrm{M}$, supplied as $\mathrm{CuSO}_{4}$.

Growth parameters, chlorophyll content and mineral content: Leaves and roots of plants were sampled after 3, 7, 11 and $15 \mathrm{~d}$ of copper application, and all the determinations were repeated at least 3 times. For dry mass determination, samples were oven dried at $105{ }^{\circ} \mathrm{C}$ until constant mass. Leaf area determination was performed using an HP Scanjet 3400 scanner and the software ImageJ (ImageJ 1.30v, NIH, Maryland, USA). Chlorophyll content was determined by a non-destructive method using the Minolta SPAD-501 (Osaka, Japan) apparatus. Results were expressed in arbitrary units (SPAD units) that are proportional to chlorophyll content (Madeira et al. 2000). For mineral composition determination ( $\mathrm{Ca}, \mathrm{Cu}, \mathrm{Fe}, \mathrm{K}, \mathrm{Mg}, \mathrm{Mn}, \mathrm{Na}$ and $\mathrm{Zn}$ ), samples of dried plant material were ashed at $480{ }^{\circ} \mathrm{C}$ in a muffle furnace, twice digested in $10 \mathrm{~cm}^{3}$ of $3 \mathrm{M} \mathrm{HCl}$ at $90{ }^{\circ} \mathrm{C}$ and analysed by flame atomic absorption spectrophotometer (Unicam Solaar M, Massachusetts, USA). Phosphorus was determined by the molybdovanadate colorimetric method using an Hitachi U-2000 (Tokyo, Japan) UV/Vis spectrophotometer.

Enzyme assays: Crude extract was obtained by maceration of ca. $0.5 \mathrm{~g}$ of leaves in the presence of $2 \%$ $(\mathrm{m} / \mathrm{m})$ insoluble polyvinylpolypyrollidone (PVP), with $1 \mathrm{~cm}^{3}$ of $100 \mathrm{mM}$ Tris-HCl buffer ( $\mathrm{pH} \mathrm{7.8),} \mathrm{containing}$ $3 \mathrm{mM}$ dithiothreithol (DTT) and $1 \mathrm{mM}$ ethylenediaminetetracetic acid (EDTA). The homogenate was centrifuged at $10000 \mathrm{~g}$ for $30 \mathrm{~min}$ (Sigma 3-18K, Osterode am Harz,

\section{Results}

In the roots of plants growing at $50 \mu \mathrm{M} \mathrm{Cu}$, endogenous $\mathrm{Cu}$ content increased 32 times compared to the control. $\mathrm{Cu}$ was also translocated to the leaves and its content increased 5 fold compared to the control (Fig. 1). Fresh masses of both roots and leaves were not significantly affected (results not shown) and root growth was only affected after $15 \mathrm{~d}$ at 25 and $50 \mu \mathrm{M} \mathrm{Cu}$. At these copper concentrations darkening of the roots was also apparent. Leaf area showed only a slight decrease for 25 and
Germany) and the supernatant was filtered through $0.20 \mu \mathrm{m}$ filters. All procedures were performed at a temperature below $4{ }^{\circ} \mathrm{C}$. Peroxidase (EC 1.11.1.7) activity was determined according to a modified Tang and Newton (2005) method. The formation of tetraguaiacol was followed for $2 \mathrm{~min}$ (at the wavelength of $470 \mathrm{~nm}$ ) in a $3.5 \mathrm{~cm}^{3}$ reaction mixture containing $30 \mathrm{mM}$ 2-methoxyphenol (guaiacol) and $4 \mathrm{mM} \mathrm{H}_{2} \mathrm{O}_{2}$ in $0.2 \mathrm{M}$ sodium acetate buffer ( $\mathrm{pH} 6.0$ ). Enzymatic activity is defined as the consumption of $1 \mu \mathrm{mol}$ of guaiacol per min and per $\mathrm{cm}^{3}$ at room temperature, using coefficient of absorbance for tetraguaiacol of $2.55 \mu \mathrm{M}^{-1} \mathrm{~cm}^{-1}$. Catalase (EC 1.11.1.6) activity was determined using a modified Aebi (1983) method, measuring the decrease in absorbance at $240 \mathrm{~nm}$ for $2 \mathrm{~min}$, in a solution containing $10 \mathrm{mM}$ of $\mathrm{H}_{2} \mathrm{O}_{2}$ in $50 \mathrm{mM}$ phosphate buffer $(\mathrm{pH} \mathrm{7.0)}$. Enzymatic activity is defined as the variation in $\mathrm{H}_{2} \mathrm{O}_{2}$ absorbance per min and per $\mathrm{cm}^{3}$ using coefficient of absorbance of $3.94 \mathrm{nM}^{-1} \mathrm{~cm}^{-1}$. Superoxide dismutase (EC 1.15.1.1) activity was measured according to a modified Rubio et al. (2002) method, measuring the increase in absorbance at $550 \mathrm{~nm}$ for $2 \mathrm{~min}$ in a solution containing $0.5 \mathrm{mM}$ xanthine, $0.05 \mathrm{mM}$ ferricytochrome $c$, $0.1 \mathrm{mM}$ EDTA and xanthine oxidase in $100 \mathrm{mM}$ potassium phosphate buffer ( $\mathrm{pH}$ 7.6). Enzymatic activity is defined as the enzyme quantity needed to inhibit the reduction of ferricytochrome-C by $50 \%$ per min and per $\mathrm{cm}^{3}$. Polyphenol oxidase (EC 1.10.3.1) activity was measured according to the modified method of Oktay et al. (1995) by measuring the increase in absorbance at $420 \mathrm{~nm}$ for $2 \mathrm{~min}$, using a reaction solution containing $30 \mathrm{mM}$ catechol in $50 \mathrm{mM}$ phosphate buffer $(\mathrm{pH} 7.0)$. Enzymatic activity is defined as the variation in catechol absorbance per min and per $\mathrm{cm}^{3}$. All measurements were performed in triplicate with samples collected from several plants.

Statistical analysis: Statistical analysis was performed using the software SPSS 13.0 (SPSS Inc, 1989-2004). The results were subjected to a one-way ANOVA using the Tukey test to check for significant differences between means $(P<0.05)$. Error bars in figures represent standard deviation.
$50 \mu \mathrm{M} \mathrm{Cu}$ in nutrient solution (results not shown). Although total biomass was not affected by these $\mathrm{Cu}$ concentrations, dry matter content increased with $\mathrm{Cu}$ concentration both in leaves and roots with significant differences at the two highest $\mathrm{Cu}$ concentrations (Fig. 1).

For plants growing in $50 \mu \mathrm{M}$ of $\mathrm{Cu}$ symptoms of chlorosis and senescence of leaves were observed. SPAD values (which are correlated to chlorophyll content) decreased during 20-d treatment for all $\mathrm{Cu}$ concentrations 
tested. There was a strong negative influence of both copper concentration and time (Fig. 2). The obtained results were fitted to exponential equations with good correlation $\left(r^{2} \geq 0.94\right)$.

The contents of $\mathrm{Na}, \mathrm{K}, \mathrm{Ca}, \mathrm{Mg}$ and $\mathrm{Fe}$ remained

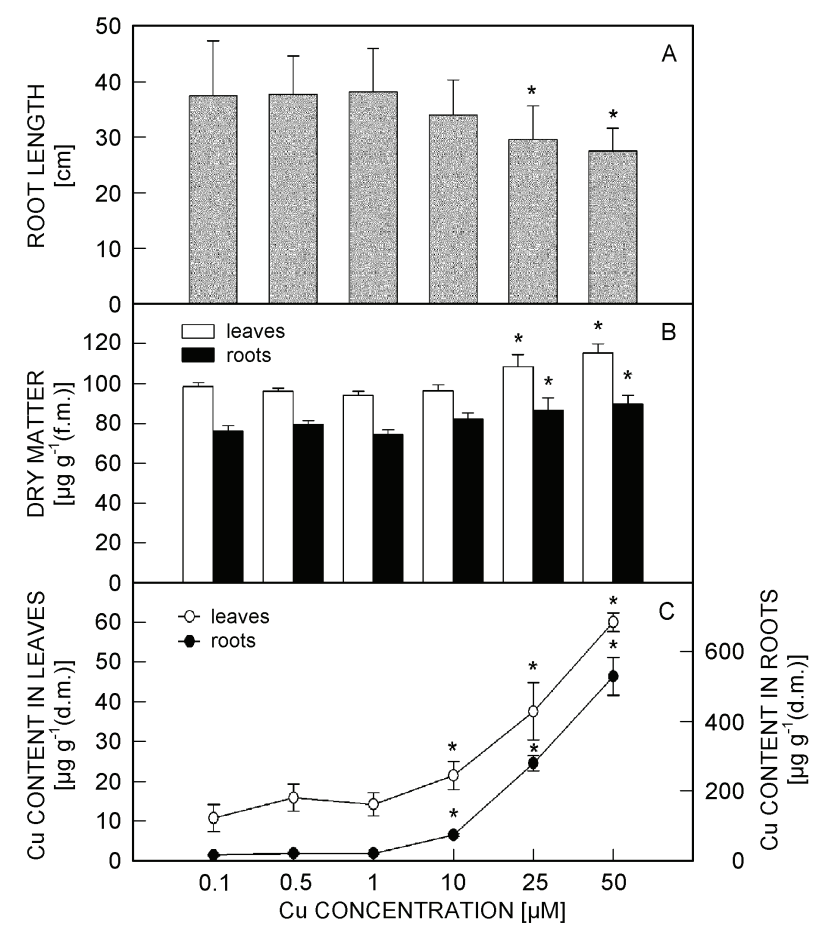

Fig. 1. Effect of different copper concentrations in nutrient solution for $15 \mathrm{~d}$ on root length $(A)$, leaf and root dry matter content $(B)$, and $\mathrm{Cu}$ contents in leaves and roots $(C)$. Significant differences $(P<0.05$, Tukey test $)$ in relation to the control $(0.1 \mu \mathrm{M})$ are indicated with an asterisk.

\section{Discussion}

Enzyme activities were monitored every $3-4 \mathrm{~d}$ in yellow lupin plants growing in hydroponic solution containing 0.1 (the control), $0.5,1,10,25$ and $50 \mu \mathrm{M} \mathrm{Cu} \mathrm{SO}$ for $15 \mathrm{~d}$. No toxic effects were detected for plants grown in 0.5 and $1.0 \mu \mathrm{M} \mathrm{Cu}$ (except for a small decrease in chlorophyll content) and at $1.0 \mu \mathrm{M} \mathrm{Cu}$, which is 10 times the control value, $\mathrm{Cu}$ contents in both roots and leaves increased only 1.3 fold compared to the control. Most of the $\mathrm{Cu}$ absorbed by the plant remained, as expected, in the roots. Translocation to the upper plant parts also occurred, mainly in the plants growing in 25 and $50 \mu \mathrm{M}$ $\mathrm{Cu}$, where the amount of $\mathrm{Cu}$ in the leaves was several times higher compared to the control and 13 and $11 \%$ of that in the roots, respectively. Proportionally, the increase in $\mathrm{Cu}$ content in roots was much higher than in leaves. During this treatment plant growth was only affected at $50 \mu \mathrm{M} \mathrm{Cu}$, which can be considered toxic for most plant species. At this $\mathrm{Cu}$ concentration some chlorosis and senescence of leaves was visible. Leaf expansion, a constant both in the leaves and in the roots. Only a decrease in Mn contents, both in roots and in leaves was detected, as well as a decrease in leaf $\mathrm{P}$ content and an increase in root $\mathrm{Zn}$ uptake (Fig. 3).

The activities of peroxidase, polyphenol oxidase, superoxide dismutase mostly initially increased and then decreased at the longer treatment duration, and also mostly increased with increased $\mathrm{Cu}$ concentration (Fig. 4). The exception was catalase that showed no significant differences for the whole time and copper concentration range.

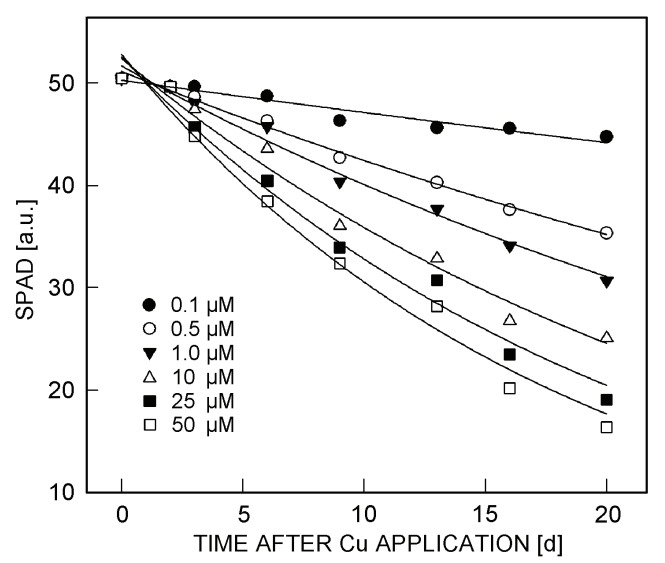

Fig. 2. Effect of $\mathrm{Cu}$ concentration in nutrient solution on chlorophyll content (measured as SPAD values) as a function of time. Corresponding exponential equations:

$0.1 \mu \mathrm{M}, \mathrm{y}=0.268 \mathrm{e}^{-0.0065 \mathrm{x}}, r^{2}=0.938$
$0.5 \mu \mathrm{M}, \mathrm{y}=51.129 \mathrm{e}^{-0.0186 \mathrm{x}}, r^{2}=0.994$
$1.0 \mu \mathrm{M}, \mathrm{y}=51.650 \mathrm{e}^{-0.0254 \mathrm{x}}, r^{2}=0.988$
$10 \mu \mathrm{M}, \mathrm{y}=52.381 \mathrm{e}^{-0.0378 \mathrm{x}}, r^{2}=0.980$
$25 \mu \mathrm{M}, \mathrm{y}=52.552 \mathrm{e}^{-0.0471 \mathrm{x}}, r^{2}=0.982$
$50 \mu \mathrm{M}, \mathrm{y}=52.798 \mathrm{e}^{-0.0547 \mathrm{x}}, r^{2}=0.982$

common target for toxic metals, was only slightly affected in our study and thus $\mathrm{Cu}$ contents in the shoots were not high enough to affect leaf expansion significantly. Potassium, which is an important element for leaf expansion, remained at a constant level in the leaves of yellow lupin during this experiment. Cuypers et al. (2000) reported that excess $\mathrm{Cu}$ significantly reduced leaf area of Phaseolus vulgaris although the effect on shoots growth was less evident.

The decrease in chlorophyll content (as shown by SPAD values) indicated that the photosynthetic system was affected and this is a frequently described effect of $\mathrm{Cu}$ toxicity (Liu et al. 2004). In heavy metal studies, it is sometimes difficult to differentiate between the direct effect of the metal and indirect effects. For example, a decrease in iron in the leaves has been reported as the consequence of heavy metal toxicity leading to a general decrease in photosynthetic capacity (Agrawal and Sharma 2006, Patsikka et al. 2002). In our case, iron content 
remained constant in the whole experiment and thus it is not the cause for the observed chlorophyll decrease, which then could be due to inhibition of chlorophyll synthesis (Fernandes and Henriques 1991) or $\mathrm{Cu}$-induced chlorophyll degradation (Liu et al. 2004, Prasad et al. 2001). The observed decrease in chlorophyll content with time was well described by exponential equation. This could indicate that chlorophyll or chloroplast destruction follow a first order kinetics.

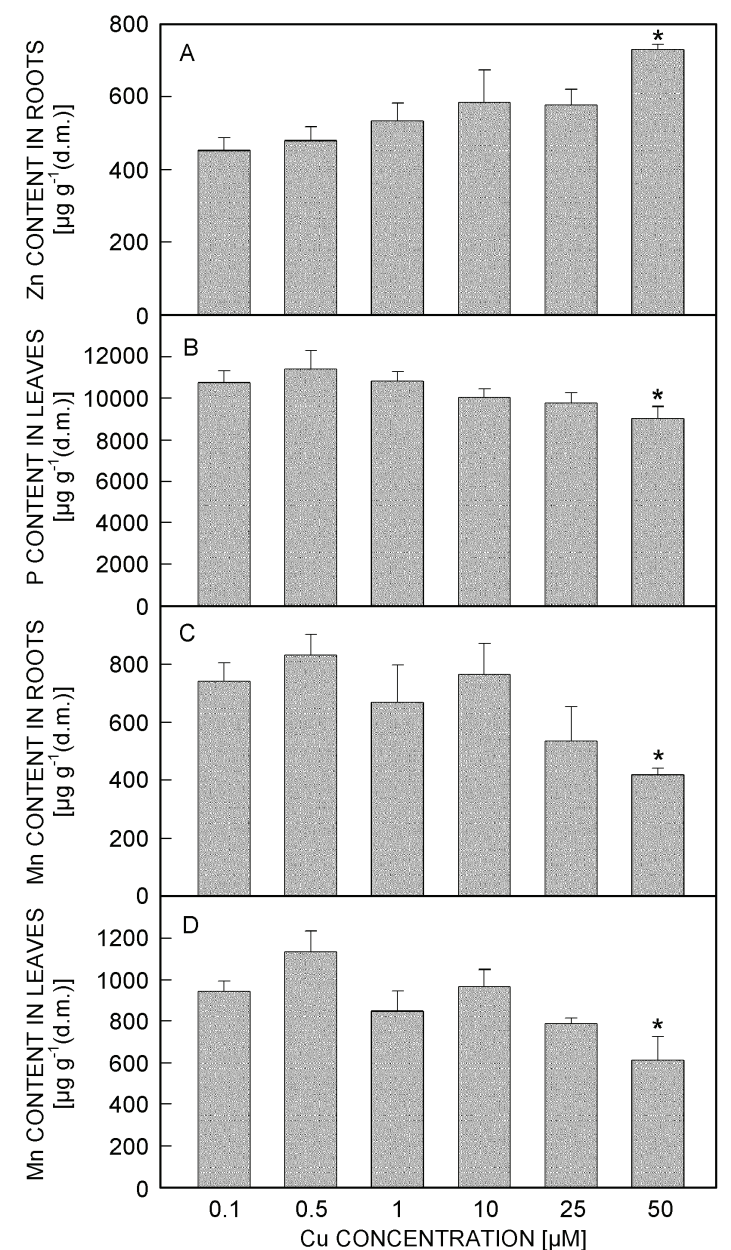

Fig. 3. Contents of selected minerals as a function of $\mathrm{Cu}$ concentration in nutrient solution, measured after $15 \mathrm{~d}$ of growth. $A-\mathrm{Zn}$ in roots, $B-\mathrm{P}$ in leaves, $C-\mathrm{Mn}$ in roots, $D-\mathrm{Mn}$ in leaves. Significant differences $(P<0.05$, Tukey test $)$ in relation to the control $(0.1 \mu \mathrm{M})$ are indicated with an asterisk.

The roots are in direct contact with the nutrient solution and are therefore the first target for toxic effects. Our results show that $\mathrm{Cu}$ was mainly sequestered in the roots and that root growth was affected at 25 and $50 \mu \mathrm{M}$ $\mathrm{Cu}$, this being a commonly described effect of toxic concentrations of $\mathrm{Cu}$ (Jiang et al. 2001, Wojcik and Tukiendorf 2003). As $\mathrm{Cu}$ can affect membrane integrity, root water content was reduced affecting pressure potential and growth (Jouili and Ferjani 2003).

Mineral nutrition can also be affected by $\mathrm{Cu}$ toxicity
(Alaoui-Sosse et al. 2004, Österås and Greger 2006, Ouzounidou et al. 1995) but it varies according to plant species and experimental conditions (Mocquot et al. 1996). In our study, the mineral contents remained remarkably stable both in roots and in leaves, with a small increase of $\mathrm{Zn}$ only in the roots, a small decrease of $\mathrm{P}$ in the leaves and a decrease of $\mathrm{Mn}$ in both roots and leaves. It thus seems that root Mn uptake system and Mn translocation was affected by $\mathrm{Cu}$ excess. However, as $\mathrm{Mn}$ transporters are thought to be linked to other nutrients (Grotz and Guerinot 2006), and these were not affected in our study, the decrease in Mn levels is probably not due to direct $\mathrm{Cu}$ action on these transporters. This could be a result of other antagonistic effects of $\mathrm{Cu}$ on $\mathrm{Mn}$ like a nonspecific effect on Mn absorption/translocation due to affected root function as proposed by Kopittke and Menzies (2006). Similar effects have been described for $\mathrm{Cu}$ toxicity in rice (Lidon and Henriques 1992).

To evaluate the plant defence against the potential oxidative stress imposed by $\mathrm{Cu}$, the activities of several antioxidative enzymes was studied; namely, GPOD, CAT, PPO and SOD. SOD is in the first line of defence against oxidative stress and our results show a transient increase in SOD enzyme activity in early periods of $\mathrm{Cu}$ toxicity ( 3 and $7 \mathrm{~d}$ ). After that the SOD activity decreased to control levels. This shows that the increase in its activity was probably related to a defensive mechanism against oxidative stress and not to other factors, as Mn decreased, $\mathrm{Fe}$ and $\mathrm{Zn}$ remained constant and only $\mathrm{Cu}$ increased. The decrease in SOD activity after the $7^{\text {th }}$ day probably indicates that enzyme expression is being directly affected by the induced $\mathrm{Cu}$ toxicity. Two enzymes usually involved in quenching $\mathrm{H}_{2} \mathrm{O}_{2}$ are catalase and peroxidase. Our results show that GPOD activity increases constantly both with time and with $\mathrm{Cu}$ concentration in nutrient solution but CAT activity was not significantly affected. It does seem that GPOD is involved in $\mathrm{H}_{2} \mathrm{O}_{2}$ elimination in yellow lupin species while CAT is not. It has been reported that when CAT activity is reduced, the activity of other ROS-scavenging enzymes increases as a compensatory mechanism (Gratão et al. 2005) and this could be the case for the observed increase in GPOD activity. This, together with the increase in SOD activity, is thus indicative of the early activation of antioxidative defence mechanisms. In fact, the role of GPOD and CAT in plants subjected to excess $\mathrm{Cu}$ seems to be highly dependant on plant species (Gratão et al. 2005, Panda 2008). Jouili and Ferjani (2003) and Tewari et al. (2006) reported an increase in CAT and GPOD activity in sunflower roots and mulberry plants, respectively, while Chatterjee and Chatterjee (2000) reported a decrease of CAT in cauliflower leaves. Rucinska et al. (1999) studied the effect of lead on yellow lupin roots and concluded that GPOD activity increased both with time and lead concentrations while the activity of SOD and CAT reached a peak and then decreased. This reinforces our conclusion that GPOD and SOD have a predominant role in the antioxidative response of this lupin species. 
PPO is a ubiquitous Cu-containing enzyme whose function in plants remains to be fully explained (Mayer 2006) but is known to be involved in plant defence against pathogens and different stresses. Our results show an increase in the activity of this enzyme but whether this is due to a putative action in relation to $\mathrm{Cu}$ induced stress or to the increase in plant $\mathrm{Cu}$ contents remains unclear. In a previous study (Martins and Mourato 2006) we observed an increase in this enzyme activity with $\mathrm{Cu}$ in tomato plants and a possible $\mathrm{H}_{2} \mathrm{O}_{2}$-quenching role was hypothesised. Other authors have suggested the involvement of PPO in response to $\mathrm{Cu}$ stress in Panax ginseng roots (Ali et al. 2006) or in lignification changes in relation to heavy metal stress in Silene paradoxa (Gonnelli et al. 2001).

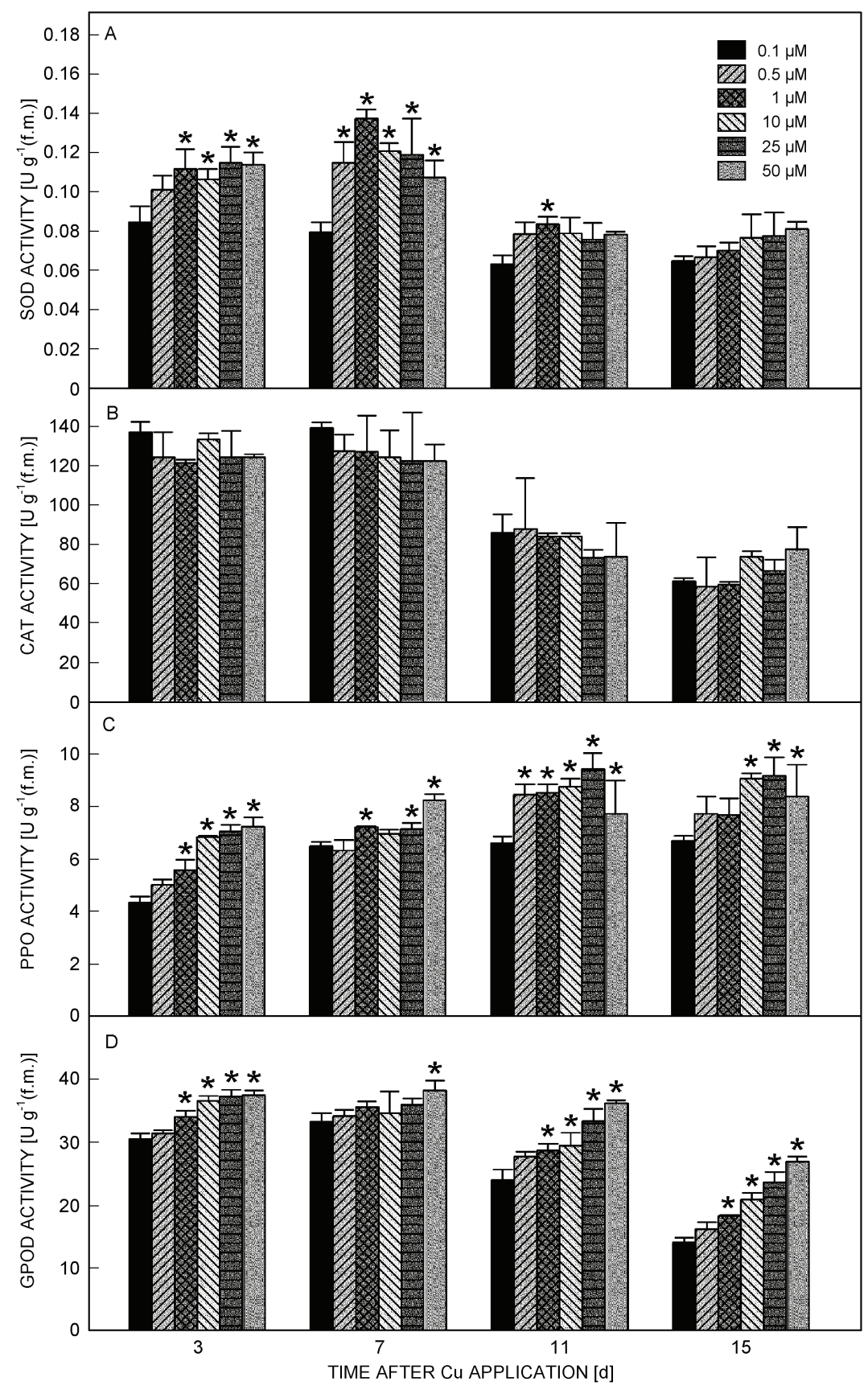

Fig. 4. Enzyme activities in leaves as a function of $\mathrm{Cu}$ concentration in nutrient solution and time. $A$ - superoxide dismutase, $B$ - catalase, $C$ - polyphenol oxidase, $D$ - guaiacol peroxidase. Significant differences $(P<0.05$, Tukey test $)$ in relation to the control $(0.1 \mu \mathrm{M})$ are indicated with an asterisk. 


\section{References}

Aebi, H.E.: Catalase. - In: Bergmeyer, U.S. (ed.): Methods in Enzymatic Analysis. III. Oxireductases, Transferases. Pp. 273-277. Verlag Chemie, Weinheim 1983.

Agrawal, V., Sharma, K.: Phytotoxic effects of $\mathrm{Cu}, \mathrm{Zn}, \mathrm{Cd}$ and $\mathrm{Pb}$ on in vitro regeneration and concomitant protein changes in Holarrhena antidysenterica. - Biol. Plant. 50: 307-310, 2006.

Alaoui-Sosse, B., Genet, P., Vinit-Dunand, F., Toussaint, M.L., Epron, D., Badot, P.M.: Effect of copper on growth in cucumber plants (Cucumis sativus) and its relationships with carbohydrate accumulation and changes in ion contents. - Plant Sci. 166: 1213-1218, 2004.

Ali, M.B., Singh, N., Shohael, A.M., Hahn, E.J., Paek, K.Y.: Phenolics metabolism and lignin synthesis in root suspension cultures of Panax ginseng in response to copper stress. - Plant Sci. 171: 147-154, 2006.

Baron, M., Arellano, J.B., Gorge, J.L.: Copper and photosystem II: a controversial relationship. - Physiol. Plant. 94: 174$180,1995$.

Brennan, R.F., Mann, S.S.: Accumulation of cadmium by lupin species as affected by $\mathrm{Cd}$ application to acidic yellow sand. - Water Air Soil Pollut. 167: 243-258, 2005.

Brun, L.A., Le Corff, J., Maillet, J.: Effects of elevated soil copper on phenology, growth and reproduction of five ruderal plant species. - Environ. Pollut. 122: 361-368, 2003.

Chatterjee, J., Chatterjee, C.: Phytotoxicity of cobalt, chromium and copper in cauliflower. - Environ. Pollut. 109: 69-74, 2000 .

Clijsters, H., Cuypers, A., Vangronsveld, J.: Physiological responses to heavy metals in higher plants: defence against oxidative stress. - Z. Naturforsch.. 54c: 730-734, 1999.

Cuypers, A., Vangronsveld, J., Clijsters, H.: The chemical behaviour of heavy metals plays a prominent role in the induction of oxidative stress. - Free Radical Res. 31: S39S43, 1999.

Cuypers, A., Vangronsveld, J., Clijsters, H.: Biphasic effect of copper on the ascorbate-glutathione pathway in primary leaves of Phaseolus vulgaris seedlings during the early stages of metal assimilation. - Physiol. Plant. 110: 512-517, 2000 .

Fernandes, J.C., Henriques, F.S.: Biochemical, physiological, and structural effects of excess copper in plants. - Bot. Rev. 57: 246-273, 1991.

Gonnelli, C., Galardi, F., Gabbrielli, R.: Nickel and copper tolerance and toxicity in three Tuscan populations of Silene paradoxa. - Physiol. Plant. 113: 507-514, 2001.

Gratão, P.L., Polle, A., Lea, P.J., Azevedo, R.A.: Making the life of heavy metal stressed plants a little easier. - Funct. Plant Biol. 32: 481-494, 2005.

Grotz, N., Guerinot, M.L.: Molecular aspects of $\mathrm{Cu}, \mathrm{Fe}$ and $\mathrm{Zn}$ homeostasis in plants. - Biochim. biophys. Acta 1763: 595608, 2006.

Gupta, H., Cuypers, A., Vangronsveld, J., Clijsters, H.: Copper affects the enzymes of the ascorbate-glutathione cycle and its related metabolites in the roots of Phaseolus vulgaris. Physiol. Plant. 106: 262-267, 1999.

Jiang, W., Liu, D., Liu, X.: Effects of copper on root growth, cell division, and nucleolus of Zea mays. - Biol. Plant. 44: 105-109, 2001.

Jouili, H., Ferjani, E.E.: Changes in antioxidant and lignifying enzyme activities in sunflower roots (Helianthus annuus L.) stressed with copper excess. - Compt. rend. Biol. 326: 639644, 2003.
Kopittke, P.M., Menzies, N.W.: Effect of $\mathrm{Cu}$ toxicity on growth of cowpea (Vigna unguiculata). - Plant Soil 279: 287-296, 2006.

Lidon, F.C., Henriques, F.S.: Copper toxicity in rice diagnostic criteria and effect on tissue Mn and Fe. - Soil Sci. 154: 130-135, 1992.

Liu, J., Xiong, Z.T., Li, T.Y., Huang, H.: Bioaccumulation and ecophysiological responses to copper stress in two populations of Rumex dentatus $\mathrm{L}$. from $\mathrm{Cu}$ contaminated and non-contaminated sites. - Environ. exp. Bot. 52: 43-51, 2004.

Madeira, A.C., Mendonca, A., Ferreira, M.E., Taborda, M.D.: Relationship between spectroradiometric and chlorophyll measurements in green beans. - Commun. Soil Sci. Plant Anal. 31: 631-643, 2000.

Maksymiec, W.: Effect of copper on cellular processes in higher plants. - Photosynthetica 34: 321-342, 1997.

Martins, L.L., Mourato, M.P.: Effect of excess copper on tomato plants: growth parameters, enzyme activities, chlorophyll and mineral content. - J. Plant Nutr. 29: 21792198, 2006.

Mayer, A.M.: Polyphenol oxidases in plants and fungi: Going places? A review. - Phytochemistry 67: 2318-2331, 2006.

Mazhoudi, S., Chaoui, A., Ghorbal, M.H., El Ferjani, E.: Response of antioxidant enzymes to excess copper in tomato (Lycopersicon esculentum Mill). - Plant Sci. 127: 129-137, 1997.

Mocquot, B., Vangronsveld, J., Clijsters, H., Mench, M.: Copper toxicity in young maize (Zea mays L.) plants: effects on growth, mineral and chlorophyll contents, and enzyme activities. - Plant Soil 182: 287-300, 1996.

Oktay, M., Kufrevioglu, I., Kocacaliskan, I., Sakiroglu, H.: Polyphenoloxidase from Amasya apple. - J. Food Sci. 60: 494-496, 1995.

Österås, A., Greger, M.: Interactions between calcium and copper or cadmium in Norway spruce. - Biol. Plant. 50: 647-652, 2006.

Ouzounidou, G., Ciamporova, M., Moustakas, M., Karataglis, S.: Responses of maize (Zea mays L) plants to copper stress. 1. Growth, mineral content and ultrastructure of roots. Environ. Exp. Bot. 35: 167-176, 1995.

Panda, S.: Impact of copper on reactive oxygen species, lipid peroxidation and antioxidants in Lemna minor. - Biol. Plant. 52: 561-564, 2008.

Patsikka, E., Kairavuo, M., Sersen, F., Aro, E.M., Tyystjarvi, E.: Excess copper predisposes photosystem II to photoinhibition in vivo by outcompeting iron and causing decrease in leaf chlorophyll. - Plant Physiol. 129: 1359$1367,2002$.

Prasad, M.N.V., Malec, P., Waloszek, A., Bojko, M., Strzalka, K.: Physiological responses of Lemna trisulca L. (duckweed) to cadmium and copper bioaccumulation. Plant Sci. 161: 881-889, 2001.

Rubio, M.C., Gonzalez, E.M., Minchin, F.R., Webb, K.J., Arrese-Igor, C., Ramos, J., Becana, M.: Effects of water stress on antioxidant enzymes of leaves and nodules of transgenic alfalfa overexpressing superoxide dismutases. Physiol. Plant. 115: 531-540, 2002.

Rucinska, R., Waplak, S., Gwozdz, E.A.: Free radical formation and activity of antioxidant enzymes in lupin roots exposed to lead. - Plant Physiol. Biochem. 37: 187-194, 1999.

Tang, W., Newton, R.J.: Peroxidase and catalase activities are involved in direct adventitious shoot formation induced by 
thidiazuron in eastern white pine (Pinus strobur L.) zygotic embryos. - Plant Physiol. Biochem. 43: 760-769, 2005.

Tewari, R.K., Kumar, P., Sharma, P.N.: Antioxidant responses to enhanced generation of superoxide anion radical and hydrogen peroxide in the copper-stressed mulberry plants. Planta 223: 1145-1153, 2006.

Van Assche, F., Clijsters, H.: Effects of metals on enzyme activity in plants. - Plant Cell Environ. 13: 195-206, 1990.
Vangronsveld, J., Clijsters, H.: Toxic effects of metals. - In: Farago, M.E. (ed.): Plants and the Chemical Elements. Biochemistry, Uptake, Tolerance and Toxicity. Pp. 149-177. VCH Verlagsgesellschaft, Weinheim 1994.

Wojcik, M., Tukiendorf, A.: Response of wild type of Arabidopsis thaliana to copper stress. - Biol. Plant. 46: 7984, 2003.

La Croix, I.F.: The New Encyclopedia of Orchids. 1500 Species in Cultivation. - Timber Press, Portland London 2008. 524 pp. USD 59.95. ISBN-13: 978-0-88192-876-1.

This Encyclopedia has been written with the aim to reflect the latest scientific research in orchid DNAs the results of which have led to a radical reassessment of orchid classification. Long-accepted names of both the species and genera have been changed. With an estimated 25000 orchid species (and over 100000 hybrids which are not included in the Encyclopedia) a rather rigorous selection was necessary. The first four short chapters are an introduction to orchids as plants, their cultivation, pests and diseases, and conservation and propagation. The main part of the Encyclopedia is a detailed description of 1500 cultivated species in 350 genera presented in alphabethic order. Each item includes a description of plant morphology and sizes, characteristics of the whole plant, leaves, flowers, inflorescences, etc. including taxonomical and etymological data and synonyms if present. Further details concern growth and native habitat of the species as well as the country of origin and valuable remarks and tips to cultivation of the plants. An important help in the identification of the species are more than 1000 excellent photographs made by Manuel Aubron. The author of the book is Isobyl La Croix, botanist at the University of Edinburgh. She has done extensive fieldwork throughout the world, but especially in Africa, where she lived for 22 years. She has written several scientific books and articles on orchids. At the end of the book a glossary of important botanical terms, a list of References, an Index of common names and another one of scientific names of the orchid plants mentioned in the Encyclopedia are added.

The broad and deep knowledge of orchids and longlasting experience in orchid cultivation reflected in the Encyclopedia are the guarantee for it will be used by scientists, collectors or people starting with orchid cultivation. 